Tohoku J. exp. Med., 1968, 96, 405-411

\title{
Mitosis of Heart Muscle Cells in Normal Rats
}

\author{
Rikuro Sasaki, Toshiaki Morishita and Shoichi Yamagata \\ Department of Internal Medicine (Prof. S. Yamagata), \\ Tohoku University School of Medicine, Sendai
}

\begin{abstract}
In order to demonstrate mitotic figures of the heart muscle cells and the interstitial cells during normal growth, colchicine was given to a total of 20 rats of various ages and mitosis in the myocardial cells was evaluated. The mitotic rate of heart muscle cells in 4 hours was $1.9-2.1 \%$ on the first day of life and it gradually decreased to $0.1 \%$ in 4 weeks and zero thereafter. The mitotic rate of interstitial cells was $2.0-2.2 \%$ on the first day of life and it similarly decreased to $0.1 \%$ in 6 months. These results seem to support our view that heart muscle cells and interstitial cells divide and increase in number with postnatal growth of the heart.
\end{abstract}

It has been demonstrated that the total cell number of the whole heart musele of rats increases up to about 4 times in 2 years from birth during the normal growth and interstitial cells further continue to increase with the growth of the animals. ${ }^{1}$ Furthermore, chemical determination of DNA content in the whole heart muscle and microspectrophotometric determination of DNA content in each nucleus of the heart muscle cell and of interstitial cell also indicate that the heart muscle cells increase in several weeks after birth and interstitial cells continue to increase in number even thereafter. ${ }^{2}$ These observations suggest that heart muscle cells may be multiplied by cell division. A few investigators have demonstrated myocardial regeneration in human heart ${ }^{3-5}$ and in experimental animals. ${ }^{6,7}$ These results, however, were not related to myocardial growth or cell division.

The present paper is concerned with mitosis in the heart muscle cells of normal rats after colchicine treatment.

\section{Materials and Methods}

A total of 20 male rats of Wistar strain were used. The age ranged from 1 day to 2 years. The animals used were not subjected to any treatment. Colcemid, a product of Ciba, was given as a mitosis inhibitor. Four hours after intraperitoneal administration of Colcemid ( $1 \mathrm{ml} / \mathrm{kg}$ of body weight), the rats were killed by decapitation. Then, the hearts were cut into small pieces and were fixed in Carnoy's or $10 \%$ formalin solution. Histological specimens were made as usual and stained with hematoxylin and eosin. Mitosis in colchicine-metaphase was searched, and the mitotic rate in 4 hours was estimated in each age.

Received for publication, August 29, 1968. 


\section{Results}

Mitosis of the heart muscle cell was shown in Figs. 1-6. Figs. 7 and 8 show mitosis of interstitial cells.

The mitotic rate of heart muscle cell in 4 hours was $1.9-2.1 \%$ in 1-day-old animals and it gradually decreased to $0.1 \%$ in 4-week-old, and no definite mitoses were found thereafter. The mitotic rate of interstitial cells was $2.0-2.2 \%$ in 1-dayold and it similarly decreased to $0.1 \%$ in 6 -month-old, and no definite mitoses were found in animals older than 6-month-old ones (Table 1).

TABLE 1. Mitotic rate of heart muscle cell and interstitial cell

\begin{tabular}{c|c|c}
\hline Age & Heart muscle cell (\%) & Interstitial cell (\%) \\
\hline 1 day & 1.9 & 2.1 \\
1 day & 2.1 & 2.1 \\
1 day & 1.9 & 2.2 \\
1 day & 2.0 & 2.0 \\
I week & 1.4 & 1.7 \\
1 week & 1.3 & 1.6 \\
2 weeks & 0.9 & 1.1 \\
2 weeks & 0.8 & 1.0 \\
3 weeks & 0.3 & 0.6 \\
3 weeks & 0.4 & 0.6 \\
4 weeks & 0.1 & 0.7 \\
4 weeks & 0.1 & 0.6 \\
2 months & 0 & 0.4 \\
2 months & 0 & 0.1 \\
2 months & 0 & 0.2 \\
3 months & 0 & 0.2 \\
6 months & 0 & 0.2 \\
6 months & 0 & 0.1 \\
1 year & 0 & 0 \\
2 years & 0 & 0
\end{tabular}

\section{DisCUSSION}

In regard to mitotic activity, adult organs can usually be classified into 3 categories: (1) organs without mitotic division, (2) organs with slight cell division, and (3) organs with frequent mitosis. The heart has long been considered to belong to the first category. It is now established beyond doubt that mitotic activity is maintained in younger rats. Mitosis inevitably causes a 'growth', because cellular proliferation is not merely replacement of one cell by two daughter cells, but it is accompanied by some spatial re-arrangement to provide a room large enough for increased cells. Thus, an expansion of the tissue is inevitable at the site of cell division.

It is unusual to observe mitotic figures in the normal heart. Since the heart muscle is apparently of syncytial structure, it is very difficult to find a characteristic metaphase pattern as seen in isolated cells such as blood cells or spermatozoa even after colchicine treatment. Figs. 1-5 show the same mitotic patterns of the 
heart muscle cells. Although they are not so characteristic in shape as those in other cells, the metaphase can be easily recognized. The nuclear membranes have completely disappeared and the chromatin appears as clumps, granules or rods. In our specimens, however, a typical spindle was not observed.

Heller, ${ }^{3}$ Warthin ${ }^{4}$ and MacMahon ${ }^{5}$ have demonstrated mitotic figures in the heart muscle cells of children, who died of diphtheric myocarditis. Furthermore, Ring ${ }^{6}$ and Robledo ${ }^{7}$ have presented evidence of myocardial regeneration following experimental myocardial injury in animals. Though there is certainly a possibility of myocardial regeneration after injury, the results were not comparable to cell division in normal myocardial growth. The present investigation is apparently a first attempt to evaluate mitosis in the heart muscle cells after colchicine treatment. Linzbach $^{8}$ has described amitosis in the heart of a baby, and Henschel ${ }^{9}$ has observed double-nucleated cells in the heart of a young man. Similar findings were obtained in two specimens of ours ( 1 and 2 week old each, Fig. 6). In general, it has been believed that amitosis is not related to increase in cell number or proliferation of cells. Therefore, the increase in cell number is not likely brought about by amitosis. In addition, these double-nucleated cells cannot be an expression of degeneration or differentiation in the young organism, because there are seldom double-nucleated cells. Consequently, it may be considered that these cells probably correspond to anaphase or telophase of normal heart cells. Rumyantsev $^{10}$ has also published his opinion that paired nuclei appears in the myocardium not as a result of amitosis but of mitosis, the course of which is modified by progressive differentiation of muscle fibers. In our specimens, it is assumed that the doses of Colcemid administered were rather inadequate and the process of cell division went through metaphase to anaphase or telophase. From these histological appearances, it is thought that the division of heart muscle cells occurs as longitudinal splitting. Thus, it is evident that there is an increase in the cell number of the heart with normal growth, and it is still equivocal whether the heart belongs to the second category-organs with slight cell division. Then, together with the results of our previous estimation of cell numbers and chemical determination of DNA content in the whole heart, this observation of mitosis appears to support strongly our view that heart muscle cells divide and increase in number with growth of the heart for several weeks after birth and interstitial cells continue to increase after birth.

\section{Acknowledgment}

We wish to express our gratitude to Prof. Tom Mori, Department of Anatomy for his suggestions.

\section{References}

1) Sasaki, R., Watanabe, Y., Morishita, T. \& Yamagata, S. Estimation of the cell numbers of heart muscles in normal rats. Tohoku J. exp. Med., 1968, 95, 177-184.

2) Sasaki, R., Watanabe, Y., Morishita, T. \& Yamagata, S. Determination of deoxy- 
ribonucleic acid content of heast, muscle and myocardial growth in normal rats. Tohoku J. exp. Med., 1968, 95, 185-192.

3) Heller, A. Über die Regeneration des Herzmuskels. Beitr. path. Anat., 1914, 57, 223231 .

4) Warthin, A.S. The myocardial lesions of diphtheria. J. infect. Dis., 1924, 35, 32-66.

5) MacMahon, H.E. Hyperplasia and regeneration of the myocardium in infants and in children. Amer. J. Path., 1937, 13, 845-854.

6) Ring, P.A. Myocardial regeneration in experimental ischemic lesions of the heart. $J$. Path. Bact., 1950, 62, 21-27.

7) Robledo, M. Myocardial regeneration in young rats. Amer. J. Path., 1956, 32, 12151239.

8) Linzbach, A.J. Die Anzahl der Herzmuskelkerne in normalen, überlasteten, atrophischen und mit Corhormon behandelten Herzkammern. Z. Kreislaufforsch., 1952, 41, $641-658$.

9) Henschel, A. Über Muskelfasermessungen und Kernveränderungen bei numeriseher Hyperplasie des Myokards. Virchou's Arch. path. Anat, 1952, 321, 283-294.

10) Rumyantsev, P.P. DNA synthesis and nuclear division in embryonal and postnatal histogenesis of myocardium (autographic study). Arkh. Anat. Gistol. i. Embriol., 1964, 47, 59 (in Russian) in Fed. Proc., 1965, 24 (trans. suppl.), T 899-T 902.

Fig. 1. Section of myocardium of a 1-day-old rat showing amitotic division of the nucleus of a heart muscle cell. Chromatin appears as unevenly distributed granules.

Fig. 2. Section of myocardium of a 7-day-old rat showing a mitotic figure of the nucleus of a heart muscle cell. Chromatin appears as clumps of granules and rods.

Fig. 3. Section of myocardium of a 2 -week-old rat showing amitotic division of the nucleus of a heart muscle cell. Chromatin appears as clumps of coarse granules.

Fig. 4. Section of myocardium of a 3-week-old rat showing amitotic figure of the nucleus of a heart musele cell. Chromatin appears as clumps of granules. 


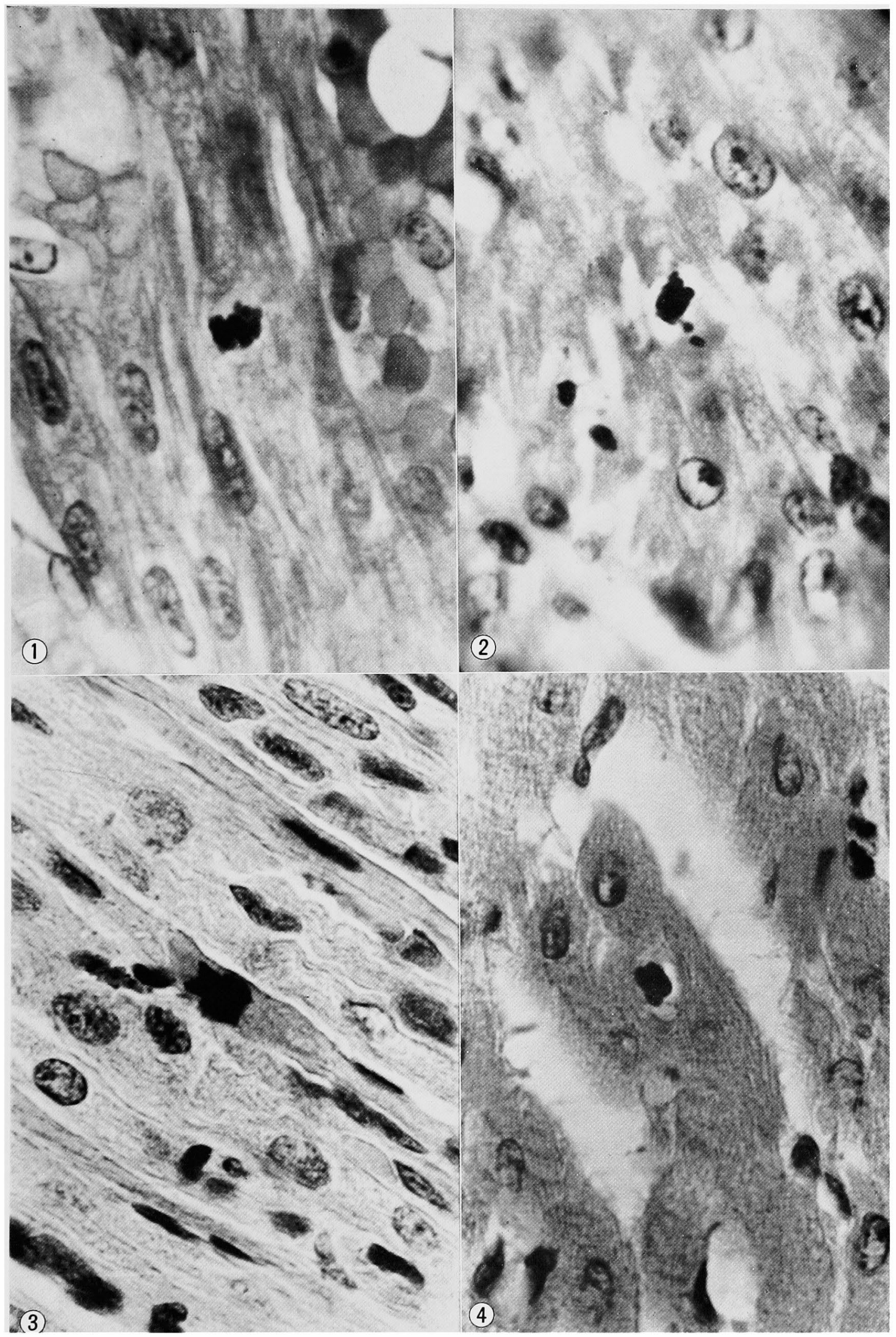


Fig. 5. Section of myocardium of a 4-week-old rat showing mitotic division of the nucleus of a heart muscle cell. Chromatin appears as clumps of fine granules.

Fig. 6. Section of myocardium of a 7-day-old rat showing a mitotic figure of the nucleus of a heart muscle cell probably in telophase. Longitudinal splitting seems to be proceeding.

Fig. 7. Section of myocardium of a 2-week-old rat showing mitotic division of the nucleus of an interstitial cell. Chromatin appears as clumps of coarse granules between muscle fibers.

Fig. 8. Section of myocardium of a 3-month-old rat showing a mitotic figure of the nucleus of an interstitial cell. The chromatin material appears as clustered rods and granules. 


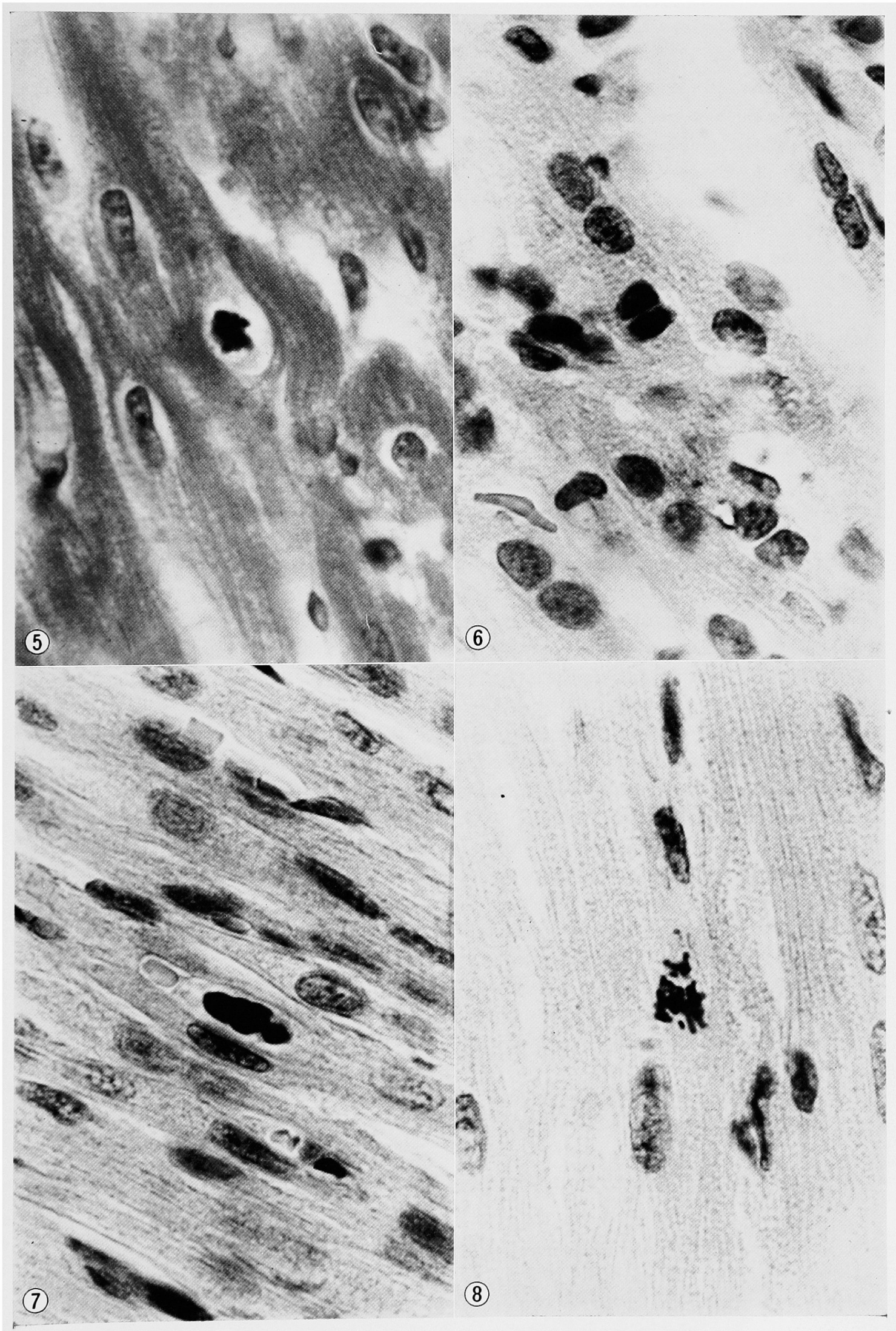

